ANNALS OF "DUNAREA DE JOS" UNIVERSITY OF GALATI
MATHEMATICS, PHYSICS, THEORETICAL MECHANICS
FASCICLE II, YEAR XII (XLIII) 2020, No. 2

DOI: https://doi.org/10.35219/ann-ugal-math-phys-mec.2020.2.05

\title{
A study on drinking water quality in SE Romania
}

\author{
Maria Cioroi ${ }^{1, *}$, Antoaneta Ene ${ }^{2,3}$ \\ ${ }^{1}$ Dunarea de Jos University of Galati, Faculty of Medicine and Pharmacy, 35 A.I. Cuza St., 800010 Galați, \\ Romania \\ ${ }^{2}$ INPOLDE interdisciplinary research network, ReForm Multidisciplinary Platform, Dunarea de Jos University \\ of Galati, 111 Domneasca St., 800201 Galati, Romania \\ 3"Dunarea de Jos" University of Galati, Faculty of Sciences and Environment, 47 Domneasca Street, 800008 \\ Galati,Romania,aene@ugal.ro \\ *maria.cioroi@ugal.ro
}

\begin{abstract}
Water is a fundamental and indispensable constituent of the human body. Small changes produce serious disorders and insufficient water intake is much less tolerated than in other deficiency. The aim of this work is the study of drinking water quality indicators in selected localities in SE Romania (Galati, Braila, Buzau, and Vrancea counties). Water samples were taken from drinking water sources (tap water, well water, spring water, filtered tap water with biological filter), frequently used by the population (15 places). They were subjected to chemical and physico-chemical analysis in order to determine the physical, chemical parameters of quality that can have an impact on the residents' health. In five water sources (Independenta (tap), Independenta (spring), Lunca/Buzau, Liesti fountain at $40 \mathrm{~m}$ depth, and Galati (biologically filtered tap water) the $\mathrm{pH}$ is below 6.5, a value that does not fit into STAS acquis in force - SR ISO 10523-2009. Oxidability index values in the majority of cases are below the maximum allowed, of $5 \mathrm{mg} \mathrm{O}_{2} / \mathrm{L}$ water, according to SR EN ISO 8467-2001; in some cases, the values exceed the limits as following: Independenta: $8 \mathrm{mg} \mathrm{O}_{2} / \mathrm{L}$; Lunca/Buzau: $10 \mathrm{mg} \mathrm{O} / 2$; Focsani spring: $9 \mathrm{mg} \mathrm{O} / 2$; Focsani tap: $8 \mathrm{mg} \mathrm{O} / \mathrm{L}$; Galati tap: $6 \mathrm{mg} \mathrm{O} / \mathrm{L}$.
\end{abstract}

Keywords: drinking water, water quality, parameters, SE Romania.

\section{INTRODUCTION}

Groundwater is an important natural resource necessary for human consumption, domestic usage, and various economic sectors and, due to its importance for human health, drinking water quality has to be permanently monitored, according to the European Union (EU) and national legislation quality standards $[1,2]$.

Water has many roles in the body, the most important ones being [3]:

- the structural role, as the main component of the body;

- the reaction medium and the intervention for all metabolic processes - contributing to maintaining homeostasis which is essential for various processes, such as absorption, transport, diffusion, osmosis, excretion;

- role in the metabolism of macronutrients;

- source of $\mathrm{Ca}, \mathrm{Mg}, \mathrm{Na}, \mathrm{K}$, and other useful substances to the body, but sometimes of undesirable elements (toxic pathogens).

Due to the fact that the physico-chemical parameters represent an important monitoring tool of the drinking water quality, the aim of this work was to assess the water quality indicators in selected localities in SE Romania from Galati, Braila, Buzau, and Vrancea counties. 


\section{EXPERIMENTAL}

Water samples were taken from various sources of drinking water (tap water, well water, spring water, filtered tap water with biological filter) (15 places), frequently used by the population in SE Romania counties (Figure 1). They were subjected to chemical and physico-chemical analysis in order to determine the physical, chemical parameters of quality that could affect the residents' health, according to Romanian legislation [3-5]. Conductivity, salinity, TDS, and $\mathrm{pH}$ measurement are performed with CONSORT C - 862 multiparameter; the volumetric analyses were done in order to obtain the chemical parameters of drinking water $[6,7]$.

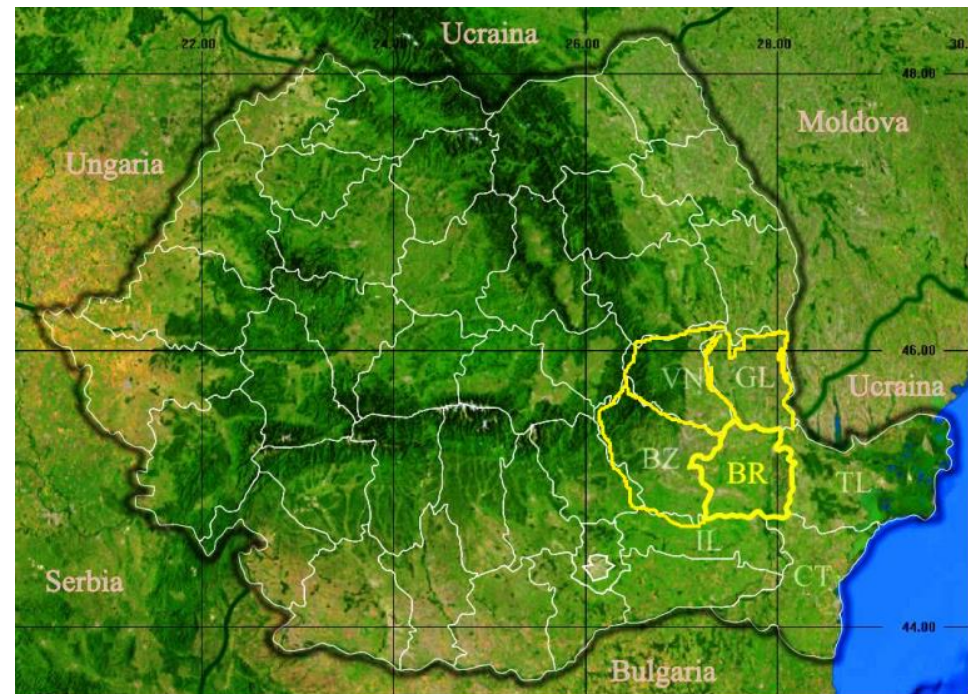

Fig. 1. The study area of drinking water quality indicators in Southeast of Romania (Galati, Braila, Buzau, Focsani)

\section{RESULTS AND DISCUSSION}

The results obtained in this study are presented as average values, together with the coefficient of variation $(\mathrm{CV})$ and standard deviation.

The study was carried out on a set of 15 samples of drinking water from various sources (tap water, fountain and well water, spring water, filtered tap water with biological filter). The results obtained from chemical and physico-chemical analyses are presented in graphical forms.

The redox potential, $\mathrm{E}_{\text {redox }}$, is an important parameter because it gives information on the reducing character of the analyzed samples which can be associated with the content of reducing substances. In Figure 2 the oxidative-reducing behavior of the analyzed waters is presented.

The environment redox character is measured by the redox potential, an experimentally measurable parameter, influenced by other parameters, among those the most important being the environment $\mathrm{pH}$ and the $\mathrm{rH}$, the last one having physical significance in aqueous media only. The $\mathrm{rH}$ implication in the biological phenomena study consists in its intrinsic definition domain (42.4 units) comparing with that of $\mathrm{pH}$ one (14 units); the $\mathrm{pH}$ contributes therefore by $66 \%$ only to the $\mathrm{rH}$ constitution [8].

The correlation between redox potential and $\mathrm{pH}$ is: $\mathrm{E}_{\mathrm{redox}}=0,029(\mathrm{rH}-2 \mathrm{pH})$ where $\mathrm{pH}$ and $\mathrm{rH}$ values are represented in Figure $3 \mathrm{a}$ and b, respectively. It is noticed that there are several water samples - Galati biologically filtered water, Liesti water, Independenta - which have the highest values of redox potential. The rest of the water samples show low values of $E$ redox, which indicates a reducing character due to the certain content of organic substances. $\mathrm{E}_{\text {redox }}$ is dependent on $\mathrm{pH}$, partial oxygen pressure (especially when low), the presence of $\mathrm{H}_{2} \mathrm{~S}$, other reducing agents in water, and dissolved organic substances. 


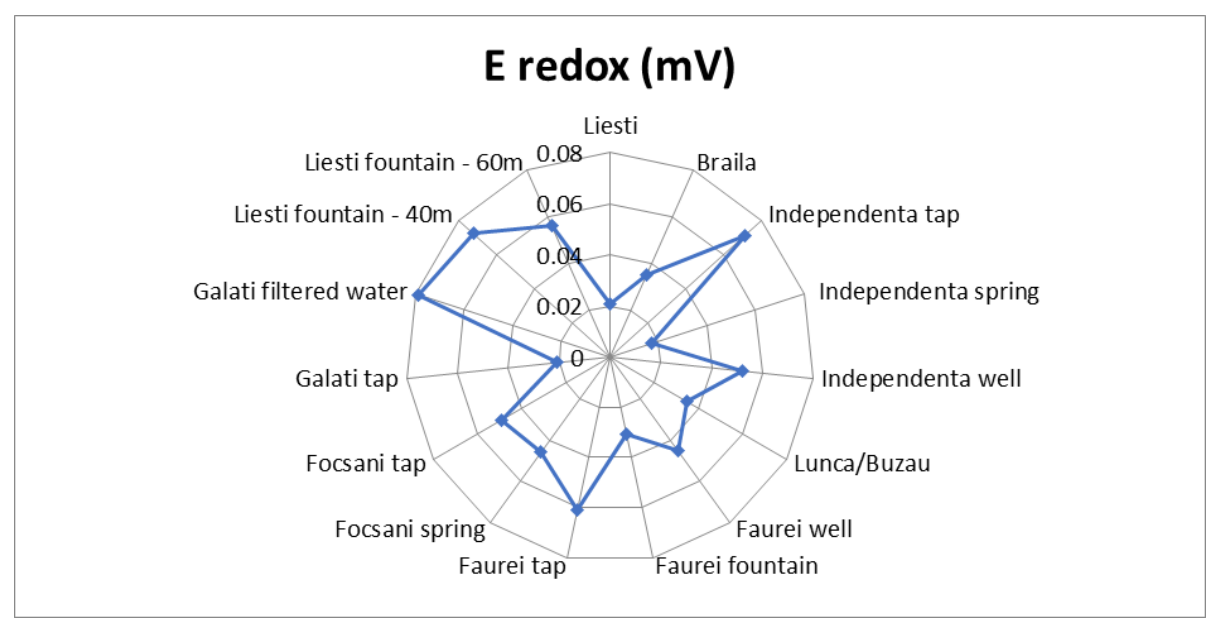

Fig. 2. Redox potential of samples from tap water, well water, spring water, filtered tap water with biological filter

The $\mathrm{pH}$ values (Fig. 3a) show the buffering capacity of the water and also give indications on the nature of the salts present in the water. A slightly basic $\mathrm{pH}$ indicates the presence in water of salts with slightly basic hydrolysis.

The $\mathrm{pH}$ values are included in most water samples in range 6 and 7.5. In some water sources (Independenta (tap), Independenta (fountain), Lunca / Buzau, Liesti fountain at $40 \mathrm{~m}$ depth, Galati (biologically filtered tap) the $\mathrm{pH}$ value is below 6, a value that does not fall within the STAS in force: STAS 6325/75 and SR ISO 10523/97.

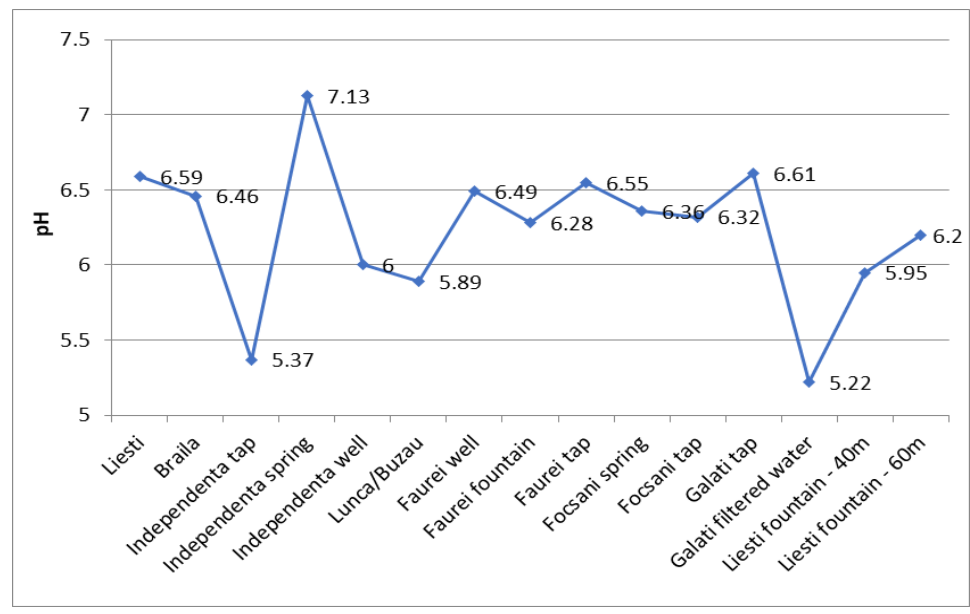

a)

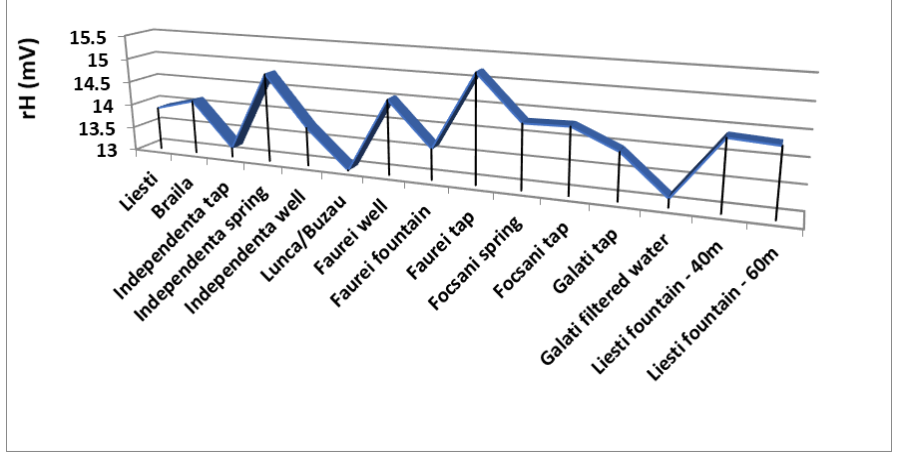

b)

Fig. 3. Values of $\mathrm{pH}(a)$ and $r H(b)$ for the analyzed water 
According to STAS $3662-62$, the allowed value for the $\mathrm{Ca}(2+)$ ions in drinking water is 100 $\mathrm{mg} / \mathrm{L}$. The exceptionally allowed value of calcium is $180 \mathrm{mg} / \mathrm{L}$. The allowed value in the case of $\mathrm{Mg}(2+)$ ions in drinking water is $50 \mathrm{mg} / \mathrm{L}$, according to STAS $6536-87$, and the exceptionally allowed value is $80 \mathrm{mg} / \mathrm{L}$.

Figure 4 presents the values of calcium and magnesium ions concentration in analyzed drinking water. In the majority of drinking water samples, the values of calcium concentration are within the limit accepted by the regulation. A very high value of the concentration of calcium ions is noticed in the fountain water from Independenta $(700 \mathrm{mg} / \mathrm{L})$. There are quantities of $\operatorname{Mg}(2+)$ ions that exceed $500 \mathrm{mg} / \mathrm{L}$ of water (Independenta fountain, Lunca / Buzau, and Faurei fountain). In the tap water sample from Focsani $\mathrm{Mg}(2+)$ is $300 \mathrm{mg} / \mathrm{L}$, and at Liesti and Faurei samples $\mathrm{Mg}(2+)$ concentration is $200 \mathrm{mg} / \mathrm{L}$. In the other water samples analyzed, the concentration of magnesium ions is below $100 \mathrm{mg} / \mathrm{L}$.

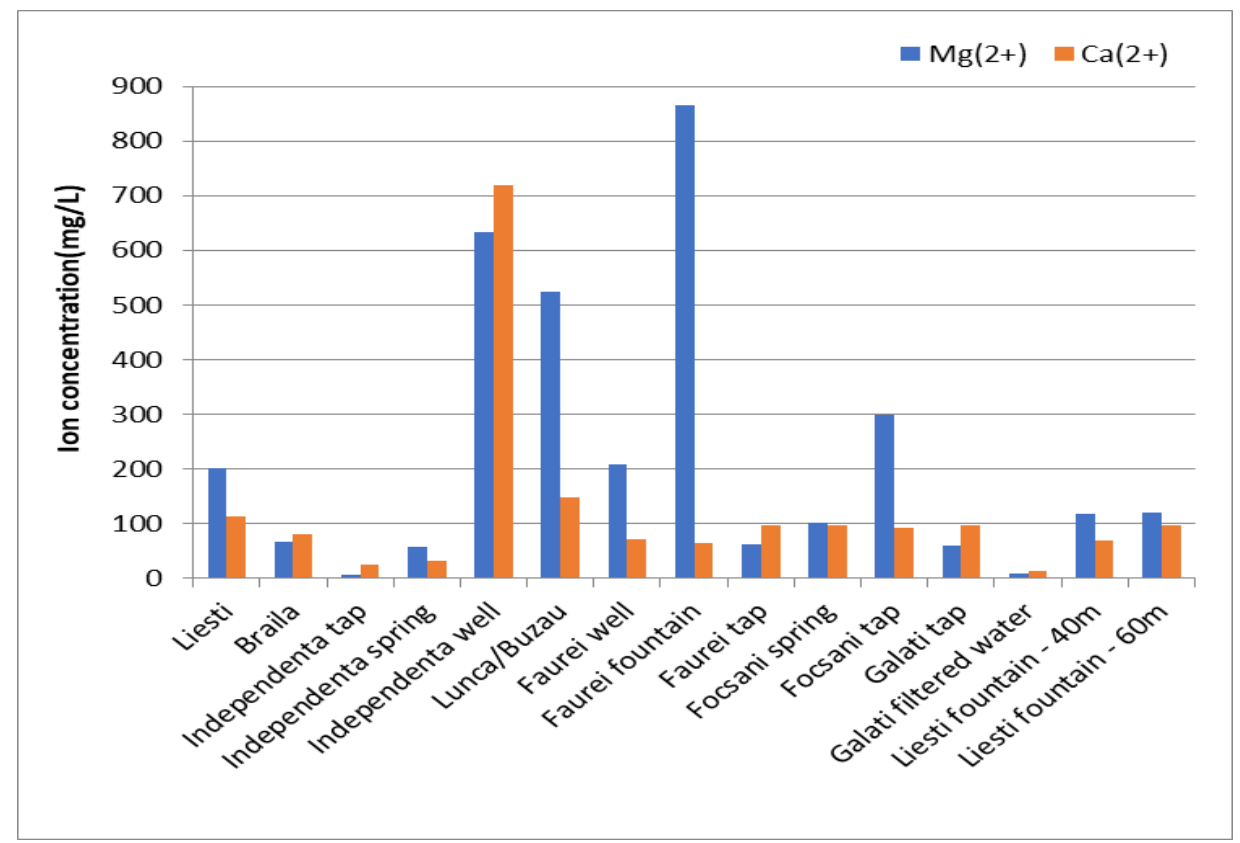

Fig. 4. Magnesium and calcium ions concentration in drinking water

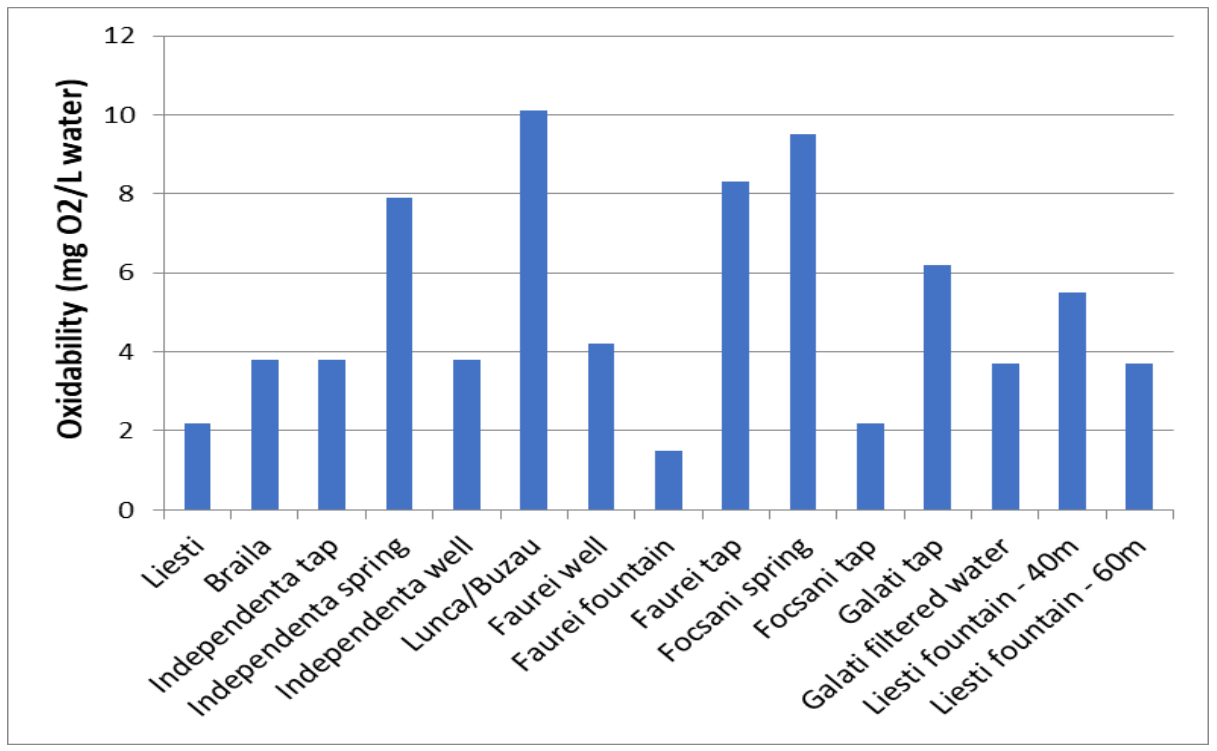

Fig. 5. Oxidability values of drinking water

The values of the oxidability index are in most cases below the maximum allowed limit, $5 \mathrm{mg}$ $\mathrm{O}_{2} / \mathrm{L}$ water, according to STAS $3002 / 85$ and SR ISO 6060/96. The highest oxidability was found in 
the water collected from the village of Lunca / Buzau, Focsani (spring), Independenta (spring), and Faurei tap (Fig. 5). Higher oxidability values indicate a high content of easily biodegradable natural organic substances.

The regulations of the World Health Organization (WHO) state that the TDS values for plain water must be: minimum $100 \mathrm{mg} / \mathrm{L}$, optimal $200-400 \mathrm{mg} / \mathrm{L}$, and maximum $500 \mathrm{mg} / \mathrm{L}$. TDS varies from source to source. TDS in the Galati sample - biologically filtered tap water - has a very low value of $125 \mathrm{mg} / \mathrm{L}$. The tap waters from Galati, Focsani, Faurei, and Braila have the TDS values in the optimal range indicated by WHO. As can be seen in Fig. 6, the drinking water samples from Independenta, Lunca/Buzau, and Faurei show very high concentration values of salts completely dissolved.

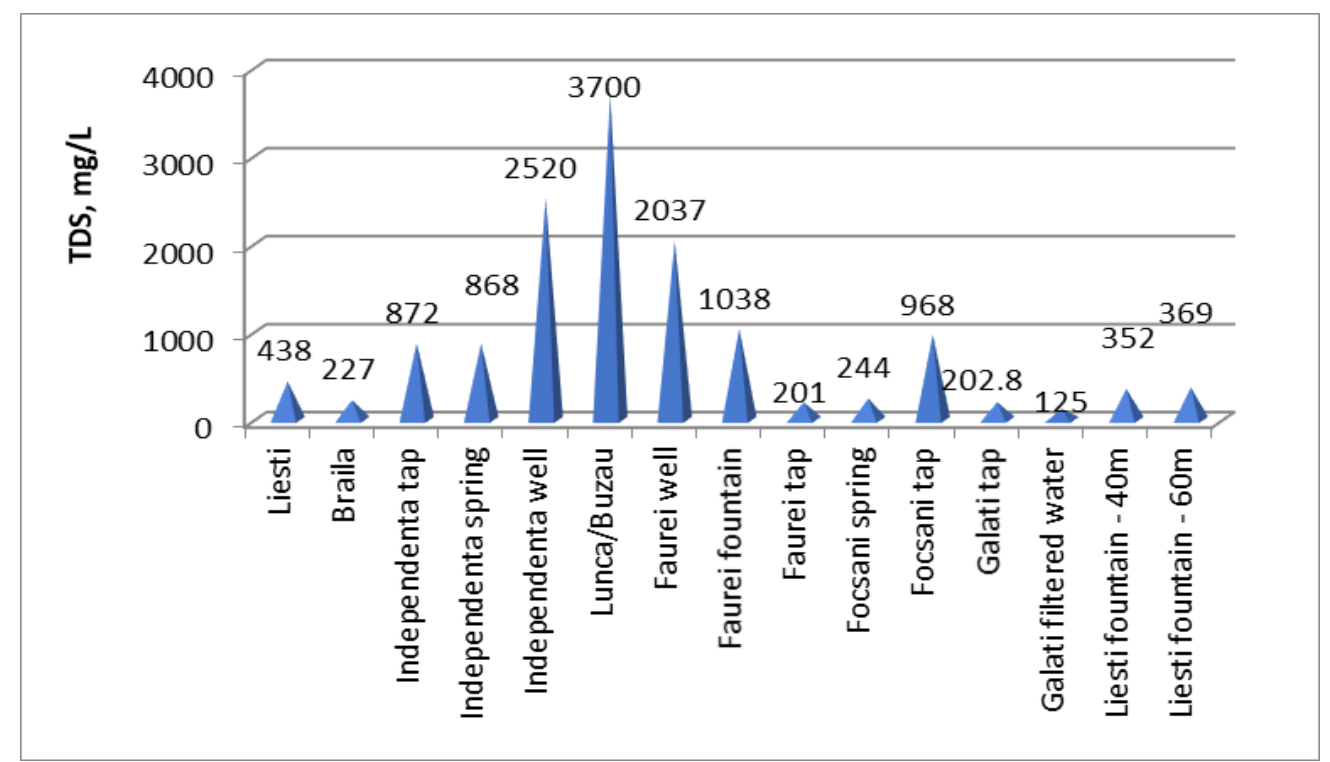

Fig. 6. TDS values (salts completely dissolved) of drinking water

In the correlation diagram of the studied parameters (Table 1), it is noticed that there is a good positive correlation between TDS, $\mathrm{pH}, \mathrm{rH}, \mathrm{Mg}(2+)$, and the oxidability index. Comparing the TDS, $\mathrm{Ca}(2+)$, and $\mathrm{Mg}(2+)$ indices, a moderate positive correlation is observed (0.49 and 0.62$)$. The higher the concentration of calcium and magnesium, the higher the content of dissolved salts. There is also a very good positive association between $\mathrm{rH}$ and $\mathrm{pH}(0.73)$ and a good negative correlation between $\mathrm{pH}$ and $\mathrm{E}$ redox, i.e. the higher the $\mathrm{pH}$, the lower the $\mathrm{E}$ redox. This correlation argues the behavior of the parameters represented in the above figures.

Table 1. Correlation diagram between principal analyzed parameters of drinking water

\begin{tabular}{lccccccc}
\hline & $\begin{array}{c}\text { Oxidability index, } \\
(\mathrm{mg} \mathrm{KMnO} / \mathrm{L})\end{array}$ & $E$ redox $(\mathrm{mV})$ & $\mathrm{pH}$ & $\mathrm{TDS}(\mathrm{mg} / \mathrm{L})$ & $\mathrm{rH}$ & $\mathrm{Ca}(2+)$ & $\mathrm{Mg}(2+)$ \\
\hline $\begin{array}{l}\text { Oxidability index, } \\
\left(\mathrm{mg} \mathrm{KMnO}_{4} / \mathrm{L}\right)\end{array}$ & 1.000 & & & & & \\
E redox $(\mathrm{mV})$ & -0.098 & 1.000 & & & & \\
$\mathrm{pH}$ & 0.192 & -0.773 & 1.000 & & & \\
$\mathrm{TDS}(\mathrm{mg} / \mathrm{L})$ & 0.205 & -0.153 & -0.136 & 1.000 & & \\
$\mathrm{rH}$ & 0.195 & -0.134 & 0.732 & -0.377 & 1.000 & \\
$\mathrm{Ca}(2+)$ & -0.063 & -0.001 & -0.060 & 0.487 & -0.094 & 1.000 \\
$\mathrm{Mg}(2+)$ & -0.236 & -0.257 & -0.026 & 0.620 & -0.316 & 0.497 & 1.000 \\
\hline
\end{tabular}


Figures 7, 8, and 9 present a comparison between tap water and filtered tap water with biological filter regarding the oxidability, the $\mathrm{Ca}$ and $\mathrm{Mg}$ concentrations, and TDS. We can see a depletion of filtered water in minerals (Ca and $\mathrm{Mg}$ ) and dissolved salts (TDS) (figs. 8, 9). Studies have shown that water with a very low total mineralization does not have organoleptic capacities (it has any taste, smell, color), but it cannot satisfy the feeling of thirst.

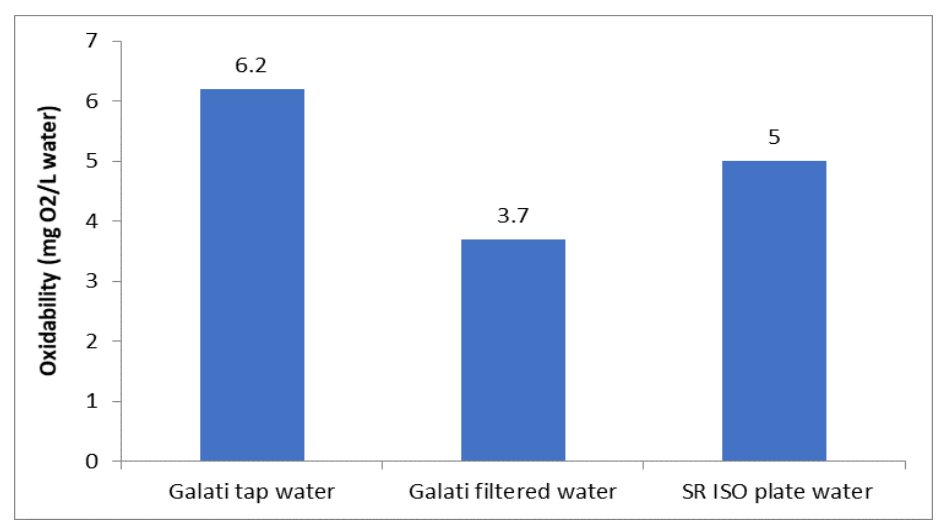

Figure 7. The comparison of oxidability values between tap water and biologically filtered water

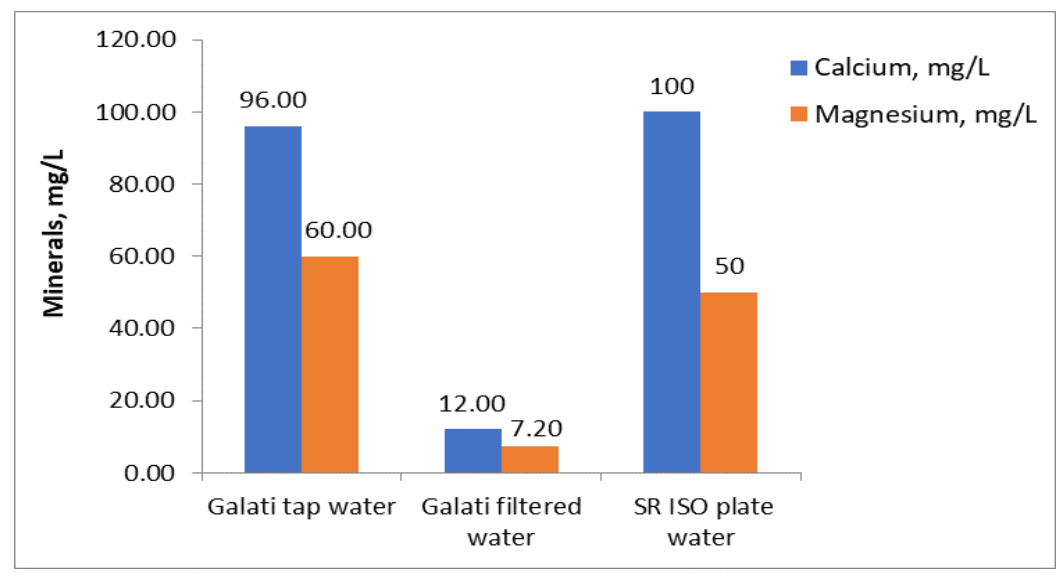

Fig. 8. The comparison of calcium and magnesium values between tap water and biologically filtered water

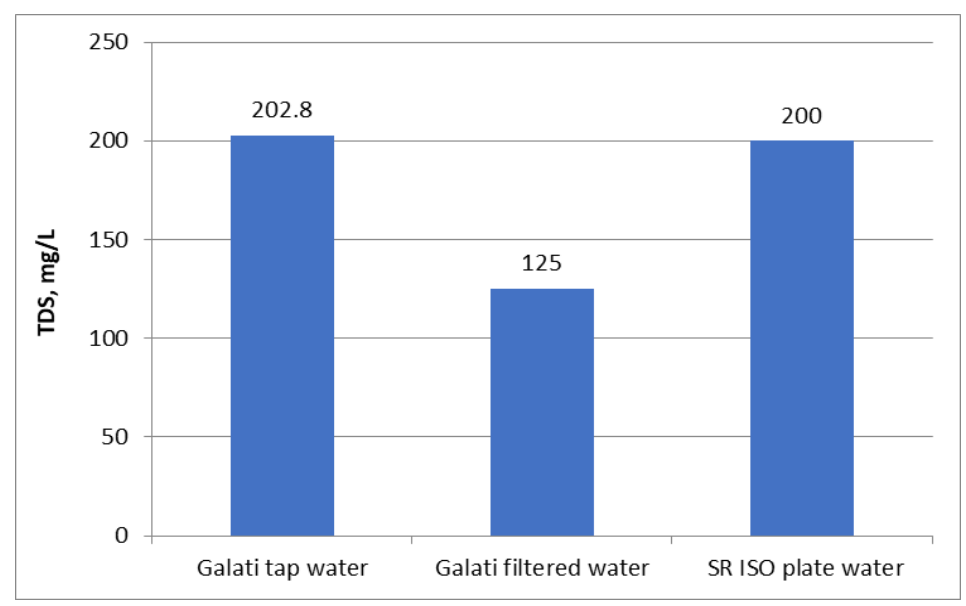

Fig. 9. The comparison of TDS values between tap water and biologically filtered water 
Consumption of water with properties close to distilled water causes changes in the water circuit in the body leading to dehydration. If not sufficiently mineralized, the water does not contain the essential minerals that are absorbed through daily consumption of water.

\section{CONCLUSIONS}

Water for human consumption has great importance for the population's health and drinking water quality has to be permanently monitored according to the EU and national legislation quality standards.

The analytical evaluation of the main physico-chemical parameters of drinking water from the selected sources in SE Romania showed that the water is intensely mineralized. Due to the increased mineralization, water from underground sources can provide a daily intake of macroelements, especially calcium and magnesium. From the point of view of the content of calcium and magnesium ions, the studied waters are considered beneficial, considering the importance of these ions for the human body. According to some researchers, magnesium consumption increases the body's resistance to infections and improves intellectual performance. It promotes digestion and maintains the integrity of the teeth. Calcium-associated magnesium fights stress and depression.

Acknowledgements: The authors would like to thank the funding of project BSB27-MONITOX (2018-2021), Joint Operational Programme Black Sea Basin 2014-2020. Part of the work was carried out in the frame of sustainability action of Project MIS ETC 1676 (INPOLDE) (2013-2015), Joint Operational Programme Romania-Ukraine-Republic of Moldova 2007-2013.

\section{References}

1. Spanos T., Ene A., Xatzixristou C., Papaioannou A., Assessment of groundwater quality and hydrogeological profile of Kavala area, Northern Greece, Romanian Journal of Physics 60(78) (2015) 1139-1150.

2. Spanos T., Ene A., Simeonova, P., Chemometric expertise of the quality of groundwater sources for domestic use, Journal of Environmental Science and Health Part A Toxic/Hazardous Substances \& Environmental Engineering 50(11) (2015) 1099 -1107.

3. Government decision No. 974 of 15 June 2004 for approval of the surveillance, sanitary inspection and water quality monitoring.

4. Law No. 458/2002 on drinking water quality.

5. Law no. 311 of 28 June 2004 amending and supplementing Law no. 458/2002 on drinking water quality.

6. Cioroi M., Chimie Analitica Cantitativa - Lucrari practice de laborator, Ed. Europlus, Galati, 2007, $116 \mathrm{pp}$.

7. Cioroi M., Chimie generala si chimia mediului - analize in monitorizarea mediului, Ed. Ars Docendi, Bucharest, 2005.

8. Zănoagă St., Mârţu S., rH Factor Implications in the Resorbative Process Study of Collagen Barriers, Journal of Romanian Medical Dentistry 12(4) (2008) 6-10. 